\title{
HYDRODYNAMIC AND HYDRODISPERSIVE CHARACTERIZATION OF A FLUVIC CAMBISOL IN THE NORTHEAST REGION OF BRAZIL ${ }^{1}$
}

\author{
ALBEDSON MIRANDA PALÁCIO FILHO ${ }^{2}$, ANDRÉ MACIEL NETTO ${ }^{3}$, MARCUS METRI CORRÊA $^{4} *$, FERNANDO \\ CARTAXO ROLIM NETO ${ }^{4}$, LÍVIA PREVIATELLO DA SILVA ${ }^{3}$, SANDERSON HUDSON DA SILVA MALTA ${ }^{5}$
}

\begin{abstract}
The determination of the hydraulic and hydrodispersive properties of soil is necessary for the understanding of water dynamics and soil solute transport, and they are used as input data in several models. Determinations of soil hydraulic and hydrodispersive parameters are usually obtained by separate methodologies. Axisymmetric infiltration tests using a single ring infiltrometer with a conservative tracer $(\mathrm{KBr})$ in the field (Beerkan-Solute) lead to the determination of the most realistic hydraulic and hydrodispersive properties of the study area. The objective of this work was the hydrodynamic and hydrodispersive characterization of an irrigated soil, classified as Fluvic Cambisol, from the lowland areas of the northeastern semi-arid region, located in the backwoods of the state of Pernambuco, in the municipality of Serra TalhadaPE. The hydrodispersive parameters were determined with the CXTFIT 2.0 program, using the CDE and MIM models. The studied soil presented hydrodynamic characteristics with high values of sorptivity $(S)$ that were associated with high values of saturated hydraulic conductivity $\left(\mathrm{K}_{\mathrm{s}}\right)$, indicating that the soil has good permeability and resistance to surface crumbling caused by rain drops or soil management. It was observed the predominance of the convective process, being the CDE model the one that presented the best performance in the transport of the $\mathrm{KBr}$ tracer under field conditions, indicating the absence of two water regions mobile and immobile in the studied soil.
\end{abstract}

Keywords: Soil hydraulic properties. Solute transport. Semi-arid.

\section{CARACTERIZAÇÃO HIDRODINÂMICA E HIDRODISPERSIVA DE UM CAMBISSOLO FLÚVICO NA REGIÃO DO NORDESTE DO BRASIL}

RESUMO - A determinação das propriedades hidráulicas e hidrodispersivas do solo é necessária para o entendimento da dinâmica da água e do transporte de solutos no solo, sendo utilizadas como dado de entrada em diversos modelos. As determinações dos parâmetros hidráulicos e hidrodispersivos do solo são normalmente obtidas por metodologias separadas. A realização de ensaios de infiltração axissimétrica utilizando um infiltrômetro de anel simples com um traçador conservativo (KBr) em campo (Beerkan-Soluto) conduz a determinações das propriedades hidráulicas e hidrodispersivas mais realistas da área em estudo. Este trabalho teve como objetivo a caracterização hidrodinâmica e hidrodispersiva de um solo irrigado, classificado como Cambissolo Flúvico, em áreas de baixios da região do Semiárido nordestino, situado na microrregião do Sertão Pernambucano, no município de Serra Talhada-PE. As determinações dos parâmetros hidrodispersivos foram realizadas com o programa CXTFIT 2.0, com uso dos modelos CDE e MIM. O solo estudado apresentou característica hidrodinâmica retratada em altos valores de sorvidade (S) associados a altos valores de condutividade hidráulica saturada $\left(\mathrm{K}_{\mathrm{s}}\right)$, indicando que o solo apresenta boa permeabilidade e resistência ao encrostamento superficial, provocado por gotas de chuva ou manejo do solo. Observou-se o predomínio do processo convectivo, sendo o modelo CDE o que apresentou melhor desempenho no transporte do traçador $\mathrm{KBr}$ em condições de campo, indicando a ausência de duas regiões água móvel e imóvel no solo estudado.

Palavras-chave: Propriedades hidráulicas do solo. Transporte de solutos. Semiárido.

\footnotetext{
"Corresponding author

${ }^{1}$ Received for publication in $02 / 21 / 2019$; accepted in $11 / 06 / 2019$.

Paper extracted from the dissertation of the first author.

${ }^{2}$ Department of Rural Technology, Universidade Federal Rural de Pernambuco, Recife, PE, Brazil; albedsonpalacio@hotmail.com ORCID: 0000-0001-7164-8996.

${ }^{3}$ Department of Nuclear Energy, Universidade Federal de Pernambuco, Recife, PE, Brazil; andmnetto@gmail.com - ORCID: 0000-00021341-5171, liviapreviatello@gmail.com - ORCID: 0000-0001-7157-451X.

${ }^{4}$ Department of Rural Technology, Universidade Federal Rural de Pernambuco, Recife, PE, Brazil; marcus.metri@gmail.com - ORCID: 0000-0002-9506-8969, fernandocartaxo@yahoo.com.br - ORCID: 0000-0002-6411-2058.

${ }^{5}$ Laboratory Co-ordination, Instituto Federal de Educação, Ciência e Tecnologia de Pernambuco, Vitória de Santo Antão, PE, Brasil, sanderson.malta@vitoria.ifpe.edu.br-ORCID: 0000-0001-6038-2600.
} 


\section{INTRODUCTION}

In recent decades, with the intensification of land use for agricultural purposes, there has been concern about the environment and an interest in studying the leaching of fertilizers (GHIBERTO; LIBARDI; TRIVELIN, 2015) and chemical pesticides (TOCCALINO et al., 2014) in the soil. Applied for the purpose of increasing agricultural productivity, fertilizers and pesticides interact with soil and water, and they may exceed the depth of the plant root system and contaminate groundwater.

In this sense, knowing the behavior and destination of water and solute in the soil is of fundamental importance, especially in issues related to environmental impact. Since the 1960 s, with the initial studies of solute transport in soils (BIGGAR; NIELSEN, 1962a,b; NIELSEN; BIGGAR, 1961), the amount of research in this area has increased considerably and with this the number of experimental situations in which mathematical modeling is applied. There are existing studies in the literature involving solute transport and other chemical substances in laboratory conditions (MILFONT et al., 2006; DING et. al., 2014; SIDOLI et al., 2016; RODRÍGUEZ-LIÉBANA; MINGORANCE; PEÑA, 2018) and field conditions (DYNIA; SOUZA; BOEIRA., 2006; COPPOLA et al., 2011; GHIBERTO; LIBARDI; TRIVELIN, 2015). However, there are few studies in Brazil related to the determination of hydrodispersive parameters under field conditions, especially with the semi-arid soils in northeastern Brazil (NETTO et al., 2013).

Similarly, determining soil hydraulic properties is crucial for describing soil water dynamics (VILLARREAL et al., 2019). Among the main hydrodynamic parameters are the soil hydraulic conductivity $(K(\theta))$ and sorptivity $(S)$. Sorptivity reflects the soil's ability to absorb water through capillary forces (PHILIP, 1957), and is one of the components governing the soil water runoff process and needs to be incorporated into any application where water adsorption or desorption occurs (VOGELMANN et al., 2017). Soil hydraulic conductivity reflects the soil's capacity to allow water passage in the soil and has been used in several numeric models that simulate the soil water dynamics.

Currently, the modeling of water and solute movement in the soil is an essential tool that is used to find ways to reduce surface and groundwater pollution. Among the various theoretical models used to determine hydrodispersive parameters, the convection-dispersion model (CDE) has been used to describe the transport of solutes under controlled laboratory or field conditions. In the case of water flow in heterogeneous soils, Van Genuchten and Wierenga (1976) incorporated the concept of mobile and immobile water developed by Coats and Smith
(1964) into the CDE model, resulting in the model known as the physical non-equilibrium model or MIM.

It is common in solute transport studies to use chemical tracers, products whose interaction with soil is insignificant and is easy to determinate. One of the most used tracers in the transport of pollutants in the soil is Bromide (Br-), which can simulate the mobility of products that, similarly being very mobile, but difficult to quantify, provides the estimation of hydrodispersive parameters for soil pollutants with greater contamination powers, such as $\mathrm{NO}_{3}^{-}$fertilizer or electrostatically neutral crop protection products.

The objective of this work was the hydrodispersive and hydrodynamic characterization of an irrigated soil field in lowland areas of the semiarid region in northeastern Brazil, located in the backwoods Pernambucano, in the municipality of Serra Talhada-PE, using the bromide tracer ( $\mathrm{Br}-)$, and comparing the performances of the $\mathrm{CDE}$ and MIM models.

\section{MATERIAL AND METHODS}

\section{Experimental Proceedings}

The study area where the experimental tests were performed is located in the municipality of Serra Talhada-PE $\left(7^{\circ} 58^{\prime} 54^{\prime \prime}\right.$ to $8^{\circ} 01^{\prime} 36^{\prime \prime} \mathrm{S}$ and $38^{\circ}$ $18^{\prime} 24^{\prime \prime}$ to $\left.38^{\circ} 21^{\prime} 21^{\prime \prime} \mathrm{W}\right)$, inserted in Cachoeira II Irrigated Perimeter. The local altitude is approximately $429 \mathrm{~m}$. The soil was classified by the Brazilian Soil Classification System as Cambissolo Flúvico, corresponding in the FAO System (FAO, 2015) to Fluvic Cambisol, with a high degree of salinization and sodification (SANTOS et al., 2013).

The regional climate is classified as semi-arid hot (high temperatures and dry), with mean temperatures between 23 and $27^{\circ} \mathrm{C}$, with precipitations of high amplitude, between 400 and $800 \mathrm{~mm}$, being distributed in higher concentrations in the first four months of the year. During the rest of the year the drought is continuous, which refers to the region there are extreme drought conditions (SOUZA et al., 2015).

The water and solute infiltration tests were executed in an area of $5,000 \mathrm{~m}^{2}$. Infiltration tests were repeated three times and carried out in three randomly chosen locations with different types of land use and occupation. The first one, was in a denser area with Atriplex nummularia Lindl; the second one, was in an area with secondary vegetation with shrubs and grasses ("Capoeira"); and in the third location commercial irrigated banana (Musa spp.) had been grown.

Soil samples were collected in the three areas for chemical and physical characterization, using an Uhland sampler. The procedure for the analysis of 
particle size fractions was initially made by screening for particles larger than $2.00 \mathrm{~mm}$ and $0.053 \mathrm{~mm}$. For fractions smaller than $0.053 \mathrm{~mm}$, sodium hexametaphosphate dispersion and sedimentation were performed using the densimeter method (TEIXEIRA et al., 2017).

The $\mathrm{pH}$ was determined in water $(1: 2.5)$. $\mathrm{P}$, $\mathrm{Na}^{+}$, and $\mathrm{K}^{+}$were extracted with Mehlich-1 $(\mathrm{HCl}$ 0.05 mol. $\left.\mathrm{L}^{-1}+\mathrm{H}_{2} \mathrm{SO}_{4} 0.0125 \mathrm{~mol} . \mathrm{L}^{-1}\right)$, and $\mathrm{P}$ was determined by colorimetry with wavelength $725 \mathrm{~nm}$ (BRAGA; DEFELIPO, 1974), while $\mathrm{Na}^{+}$and $\mathrm{K}^{+}$ were determined by flame photometry. Exchangeable $\mathrm{Al}^{3+}$ was extracted with 1 mol. $\mathrm{L}^{-1} \mathrm{KCl}$ solution and the potential acidity $(\mathrm{H}+\mathrm{Al})$ with a $\mathrm{pH} 7.0$ calcium acetate buffered solution $\left(0.5 \mathrm{~mol} . \mathrm{L}^{-1} \mathrm{CH}_{3} \mathrm{COO}_{2} \mathrm{Ca}\right)$, and determined by titration. All analyses were performed according to the methodology described by Silva (2009). Based on the results of the chemical analysis, the sum of bases (SB) and cation exchange capacity (CEC) were calculated. The organic matter (O.M.) was determined based on the methodology proposed by SILVA (2009), through wet oxidation with potassium dichromate in sulfuric medium $\left(\mathrm{K}_{2} \mathrm{Cr}_{2} \mathrm{O}_{7}\right) 0.0667$ mol.L $\mathrm{L}^{-1}$, and dosed by ammonium ferrous sulphate titration.

The infiltration method employed was the Beerkan method (LASSABATÈRE et al., 2006). An iron ring with a diameter of $0.13 \mathrm{~m}$ and a height of $0.1 \mathrm{~m}$ was installed at a depth of $0.01 \mathrm{~m}$, from the soil surface, with the aim of not destroying the soil and ensuring an axisymmetric infiltration into its surface. Known volumes of water were poured into the ring (infiltrometer) and the time required for the infiltration of each volume was measured. The water volume of $200 \mathrm{~mL}$ was chosen to avoid hydraulic load in the soil surface, and consequently, forced flow. The procedure of adding the volumes of water into the ring was repeated until a constant infiltration rate was found, when it was considered that the flow reached the steady state. Reached the steady state regime, four volumes containing each one $100 \mathrm{~mL}$ of the $\mathrm{KBr}$ solution $\left(1 \mathrm{~mol} . \mathrm{L}^{-1}\right)$ were applied in the soil. The initial volumetric moisture $\theta_{i n i}\left(\mathrm{~m}^{3} \cdot \mathrm{m}^{-3}\right)$, initial soil bromide concentration $C_{i n i}\left(\mathrm{mg} . \mathrm{L}^{-1}\right)$, and dry bulk density $\rho_{d}\left(\mathrm{~kg} . \mathrm{m}^{-3}\right)$, in the layers of $0-0.05,0.05$ 0.10 , and $0.10-0.15 \mathrm{~m}$, were measured from undisturbed soil samples collected near to the area where the infiltration tests were carried out, with an adapted Uhland sampler for three PVC cylinders, each one was $0.05 \mathrm{~m}$ high and $0.05 \mathrm{~m}$ in diameter (Figure 1-a). After the infiltration test and the addition of the tracer $\left(\mathrm{Br}^{-}\right)$, the soil was sampled in the center of the cylinder up to a depth of $0.15 \mathrm{~m}$ with the same Uhland sampler, but using a ring $0.01 \mathrm{~m}$ high and $0.05 \mathrm{~m}$ in diameter; each sample (Figure 1-b), a total of 15 samples, were used to measure the final water volumetric content, $\theta_{\mathrm{f}}\left(\mathrm{m}^{3} \cdot \mathrm{m}^{-3}\right)$ and bromide concentration in the soil, $C_{r}\left(\mathrm{mg} \mathrm{L}^{-1}\right)$.

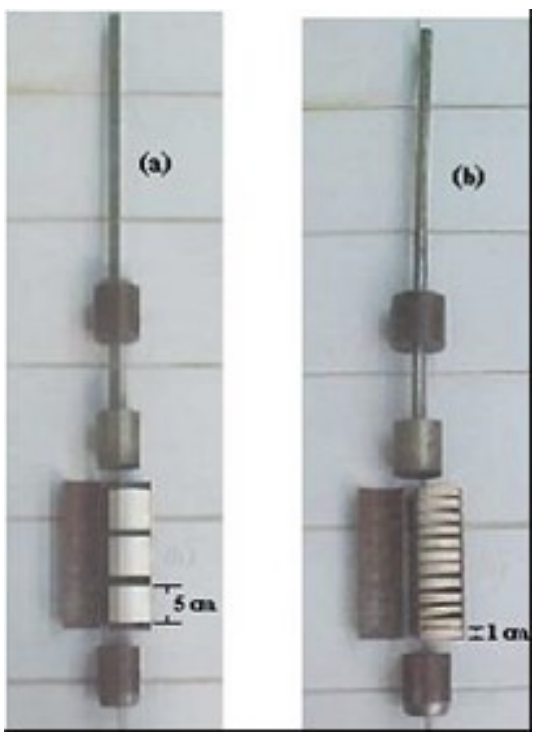

Figure 1. Samplers: (a) Cylinders $0.05 \mathrm{~m}$ high (b) Cylinders $0.01 \mathrm{~m}$ high (Netto et al., 2013).

In the laboratory, to obtain the $\mathrm{Br}^{-}$ concentration, $100 \mathrm{~mL}$ of deionized water were added, and agitated with a glass stick, aiming to extract the supernatant after 24 hours, when happened the solid particles sedimentation. Then, the samples were taken to the oven which was at a temperature of $105^{\circ} \mathrm{C}$, where they spent 24 hours in order to obtain the dry mass $(M s)$ which was used to calculate the initial moisture and dry bulk density.

\section{Soil Hydraulic Properties}

In the Beerkan method, the infiltration process is used to estimate the sorptivity $(S)$ and saturated hydraulic conductivity $\left(K_{s}\right)$. For this, the soil water retention curves $\theta(\mathrm{h})$ and saturated hydraulic conductivity $K(\theta)$ are described, respectively, by the Van Genuchten (1980) and 
Brooks and Corey (1964) models, where $m=1-(2 / n)$ (Burdine (1953) restriction):

$$
\begin{aligned}
& K(\theta)=K_{s} \cdot\left(\frac{\theta-\theta_{r}}{\theta_{s}-\theta_{r}}\right)^{\eta} \\
& \frac{\theta-\theta_{r}}{\theta_{s}-\theta_{r}}=\left[1+\left(\frac{h}{h_{g}}\right)^{n}\right]^{-m}
\end{aligned}
$$

where $\theta$ is the volumetric soil water content $\left(\mathrm{m}^{3} \cdot \mathrm{m}^{-3}\right)$, $\theta_{s}$ is the saturated volumetric water content $\left(\mathrm{m}^{3} \cdot \mathrm{m}^{-3}\right)$, $\theta_{r}$ is the residual volumetric water content, and $\mathrm{h}$ is the matric potential $(\mathrm{m})$. For most soils, $\mathrm{q}_{\mathrm{r}}$ is very small and can be considered equal to zero, causing the equations to have five unknown parameters: two shape parameters ( $\mathrm{n}$ or $\mathrm{m}$ and $\eta$ ) and three scale parameters $\left(\theta_{\mathrm{s}}, \mathrm{h}_{\mathrm{g}}\right.$, and $\left.\mathrm{K}_{\mathrm{s}}\right)$. The shape parameters are related to the texture, while the scale parameters depend on the soil structure.

Haverkamp and Parlange (1986) determined the shape parameter $(N)$, assuming a similarity between the shape of the soil water retention curve and the particle size distribution curve $F(D)$ :

$$
F(D)=\left[1+\left(\frac{D_{g}}{D}\right)^{N}\right]_{\text {with }}^{-M} \mathrm{M}=1-\frac{2}{\mathrm{~N}}
$$

where $D$ is the effective soil particle diameter (m) and $D_{g}$ is the particle size scale parameter (m). The parameters $M, N$, and $D_{g}$ are obtained by fitting equation (3) fitting to the data of the soil particle size. The shape parameters of the retention curve $(n$ and $m$ ) are calculated using the shape index of the medium $\left(p_{m}\right)$, using equations (4), (5) and (6):

$$
\begin{aligned}
& m=\frac{1}{p_{m}} \cdot\left(\sqrt{1+p_{m}^{2}}-1\right) \\
& n=\frac{2}{1-m} \\
& p_{m}=\left(\frac{M \cdot N}{1+M}\right) \cdot(1+k)^{-1}
\end{aligned}
$$

where $k$ is a coefficient defined by Fuentes et al. (1998):

$$
k=\frac{2 s-1}{2 s(1-s)}
$$

where $s$ is the relative fractal dimension, determined as a function of soil porosity $(\phi)$ :

$$
(1-\phi)^{s}+\phi^{2 s}=1 \text { para } 0.5<\mathrm{s}<1
$$

In the case of the Brooks and Corey (1964) hydraulic conductivity curve equation, its shape parameter, $\eta$, can be expressed as a function of the product of the shape parameters of the retention curve:

$$
\eta=\frac{2}{m \cdot n}+2+\rho
$$

The scale parameters $\left(h_{g}\right.$ and $\left.K_{s}\right)$ are estimated by minimizing the sum of the squares of the difference between observed and calculated infiltrated water columns. The calculated columns were obtained by the infiltration equation of Haverkamp et al. (1994), applied for a short time:

$\mathrm{I}_{3 D}=S \sqrt{t}+\left[\mathrm{K}_{i n i}+\frac{2-\beta}{3}\left(\mathrm{~K}_{\mathrm{s}}-\mathrm{K}_{i n i}\right)+\frac{\gamma S^{2}}{r \Delta \theta}\right] \cdot t$

$I_{3 D}=\left(\mathrm{K}_{s}+\frac{\gamma \mathrm{S}^{2}}{r \Delta \theta}\right) \cdot t+\frac{\mathrm{S}^{2}}{2\left(\mathrm{~K}_{s}-\mathrm{K}_{\text {ini }}\right)(1-\beta)} \cdot \ln \left(\frac{1}{\beta}\right)$

where $I_{3 D}$ represents the accumulated threedimensional infiltration $\left(\mathrm{m}^{3} \cdot \mathrm{m}^{-2}\right) ; S$ is the sorptivity $\left(\mathrm{m} . \mathrm{s}^{-1 / 2}\right) ; \mathrm{t}$ is the infiltration time (s); $K_{s}$ and $K_{i n i}$ are the hydraulic conductivities of the soil, respectively corresponding to the $\theta_{s}$ and $\theta_{i n i} ; \beta$ is the form parameter equal to $0.6 ; r$ is the ring radius $(\mathrm{m}) ; \gamma$ is a constant of proportionality equal to 0.75 and $\Delta \theta$ is the variation between the final $\left(\theta_{s}\right)$ and initial $\left(\theta_{\text {ini }}\right)$ volumetric water content of the soil during the infiltration test. The program BEST was used, which was developed in the Laboratoire d'étude des Transferts en Hydrologie et Environnement (LASSABATÈRE et al., 2006).

After the determination of $\theta_{s}$ and $K_{s}$, the parameter $h_{g}$ was obtained by equation (12) (LASSABATÈRE et al., 2006):

$$
h g=-\frac{S^{2}}{c_{p}\left(\theta_{s}-\theta_{i n i}\right)\left[1-\left(\frac{\theta}{\theta_{s}}\right)^{\eta}\right] \cdot k_{s}}
$$

where $c_{p}$ is a parameter that only depends on shape parameters $n, m$ and $h$ :

$$
\mathrm{c}_{\mathrm{p}}=\Gamma\left(1+\frac{1}{\mathrm{n}}\right) \cdot\left[\frac{\Gamma\left(\mathrm{n} \eta-\frac{1}{\mathrm{n}}\right)}{\Gamma(\mathrm{n} \eta)}+\frac{\Gamma\left(\mathrm{n} \eta+\mathrm{m}-\frac{1}{\mathrm{n}}\right)}{\Gamma(\mathrm{n} \eta+\mathrm{m})}\right.
$$

where $\Gamma$ is the gamma function.

\section{Determination of Mobile Water Fraction $(\Phi)$}


The method of analysis proposed by Clothier, Kirkham and Mclean (1992) to estimate the mobile water fraction $(\Phi)$ in the soil was used in this study. The relation between the mobile volumetric content $\left(\theta_{m}\right)$ and the total volumetric content $(\theta)$ was calculated from the total solute concentration of the first centimeter of soil, sampled at the end of the tracer infiltration experiment, assuming that there was no solute exchange between mobile and immobile water regions during the time and at the depth of sampling (equation 14).

$$
\Phi=\frac{\theta_{\mathrm{m}}}{\theta}=\frac{\mathrm{C}\left(\mathrm{z}_{0}, \mathrm{t}_{\mathrm{sol}}\right)-\mathrm{C}_{\mathrm{ini}}}{\mathrm{C}_{0}-\mathrm{C}_{\mathrm{ini}}}
$$

where $C_{i n i}$ is the initial concentration in the soil (mg. $\mathrm{L}^{-3}$ ) and $C_{0}$ is the applied solution concentration (mg. $\left.\mathrm{L}^{-3}\right)$.

\section{Hydrodispersive Characterization}

To estimate the hydrodispersive parameters, an adjustment was made in the analytical solution of the CDE and MIM transport equations, with the aid of the CXTFIT 2.0 (TORIDE; LEIJ; VAN GENUCHTEN, 1995). For the convectiondispersion model (CDE) the dimensionless equation is expressed as:

$$
\mathrm{R} \frac{\partial \mathrm{C}_{r}}{\partial \mathrm{T}}=\frac{1}{\mathrm{P}} \frac{\partial^{2} \mathrm{C}_{r}}{\partial \mathrm{Z}^{2}}-\frac{\partial \mathrm{C}_{r}}{\partial \mathrm{Z}}
$$

where $C_{r}$ is the relative resident concentration; $T$ is the number of pore volume; $Z$ is the dimensionless spatial coordinate; $P$ is the Péclet number and $R$ is the retardation factor. In Table 1 the dimensionless parameters for the CDE model are shown.

Table 1. Dimensionless parameters for the CDE model

\begin{tabular}{llllll}
\hline Parameters & $\mathrm{T}$ & $\mathrm{Z}$ & $\mathrm{P}$ & $\mathrm{R}$ & $\mathrm{C}$ \\
\hline Expressions & $\mathrm{vt}$ & $\frac{\mathrm{Z}}{\mathrm{L}}$ & $\frac{\mathrm{vL}}{\mathrm{D}}$ & $1+\frac{\rho_{\mathrm{d} \mathrm{K}}}{\theta}$ & $\frac{\mathrm{C}_{r}}{\mathrm{C}_{0}}$ \\
\hline
\end{tabular}

$v$ - mean solution velocity $\left(\mathrm{m} . \mathrm{s}^{-1}\right) ; t-$ time $(\mathrm{s}) ; L$ - total distance traveled by the solution $(\mathrm{m}) ; z$ - position coordinate $(\mathrm{m}) ; D-$ hydrodynamic dispersion coefficient $\left(\mathrm{m}^{2} . \mathrm{s}^{-1}\right) ; \mathrm{r}_{\mathrm{d}}-$ dry bulk density $\left(\mathrm{kg} \cdot \mathrm{m}^{-3}\right) ; K_{d}$ - partition coefficient $\left(\mathrm{m}^{3} \cdot \mathrm{kg}^{-1}\right) ; \theta$ - volumetric water content $\left(\mathrm{m}^{3} . \mathrm{m}^{-3}\right) ; C_{r}-\mathrm{Br}^{-}$resident concentration (mg. $\left.\mathrm{L}^{-3}\right)$ and $C_{0}-\mathrm{Br}^{-}$initial concentration applied $\left(\mathrm{mg} . \mathrm{L}^{-3}\right)$.

The two-water-region model, mobile and immobile (MIM), assumes that the liquid phase can be partitioned into two regions, mobile and immobile, in the dimensionless form, and can be described by the following equations:

$$
\begin{gathered}
\beta R \frac{\partial C r_{1}}{\partial T}+(1-\beta) R \frac{\partial C r_{2}}{\partial T}=\frac{1}{P} \frac{\partial^{2} C r_{1}}{\partial Z^{2}}-\frac{\partial C r_{1}}{\partial Z} \\
(1-\beta) R \frac{\partial C r_{2}}{\partial \mathrm{T}}=\omega\left(\mathrm{Cr}_{1}-\mathrm{Cr}_{2}\right)
\end{gathered}
$$

where $\mathrm{Cr}_{1}$ and $\mathrm{Cr}_{2}$ are, respectively, the tracer concentration in the mobile and immobile regions; $f$ is the mobile water fraction; $(1-f)$ is the immobile water fraction; $\beta$ is the partition coefficient between the two regions; and $\omega$ is the Damköhler number, which represents the mass transfer coefficient for the two regions. The retardation factor $(R)$ is described in the MIM model as:

$R=1+\frac{\theta_{i m}}{\theta_{m}}=1+\frac{\left(\theta-\theta_{m}\right)}{\theta_{m}}=1+\frac{\theta}{\theta_{m}}-1=\frac{1}{\Phi}$
This approximation of $R$ is only possible for small soil volumes, because in this case it can be considered that the mobile resident concentration has approximately the same value of immobile resident concentration, as determined by the Clothier, Kirkham and Mclean (1992) method.

\section{RESULTS AND DISCUSSION}

\section{Soil Physics Analysis}

The dry bulk density was lower in the area with banana cultivation when compared with the other two areas, which was expected due to cultural treatments, such as soil preparation, and the incorporation of organic matter, such as crop remains (Table 2).

From the particle size analysis, the soil texture was loamy sand and the particle size distribution was very similar in the three areas (Table 2 and Figure 2). In the area with Atriplex, the soil had a higher percentage of fine material (fine sand and silt). 
Table 2. Soil texture and classification

\begin{tabular}{ccccccccc}
\hline $\begin{array}{l}\text { Sample } \\
(0-0.20) \mathrm{m}\end{array}$ & $\begin{array}{c}\text { Sand } \\
(\%)\end{array}$ & $\begin{array}{c}\text { Silt } \\
(\%)\end{array}$ & $\begin{array}{c}\text { Clay } \\
(\%)\end{array}$ & $\begin{array}{c}\rho_{\mathrm{d}} \\
\mathrm{g} . \mathrm{cm}^{-3}\end{array}$ & $\begin{array}{c}\mathrm{Dp} \\
\mathrm{g} \cdot \mathrm{cm}^{-3}\end{array}$ & $\mathrm{Pt}(\%)$ & Texture & $\begin{array}{c}\text { Pedological } \\
\text { classification }\end{array}$ \\
\hline Atriplex & 67.18 & 24.62 & 8.21 & 1.250 & 2.62 & 52.3 & Loamy Sand & Cambisol \\
Capoeira & 73.80 & 17.30 & 8.90 & 1.284 & 2.56 & 49.8 & Loamy Sand & \\
Banana & 71.74 & 20.02 & 8.24 & 1.165 & 2.52 & 53.8 & Loamy Sand & \\
\hline
\end{tabular}

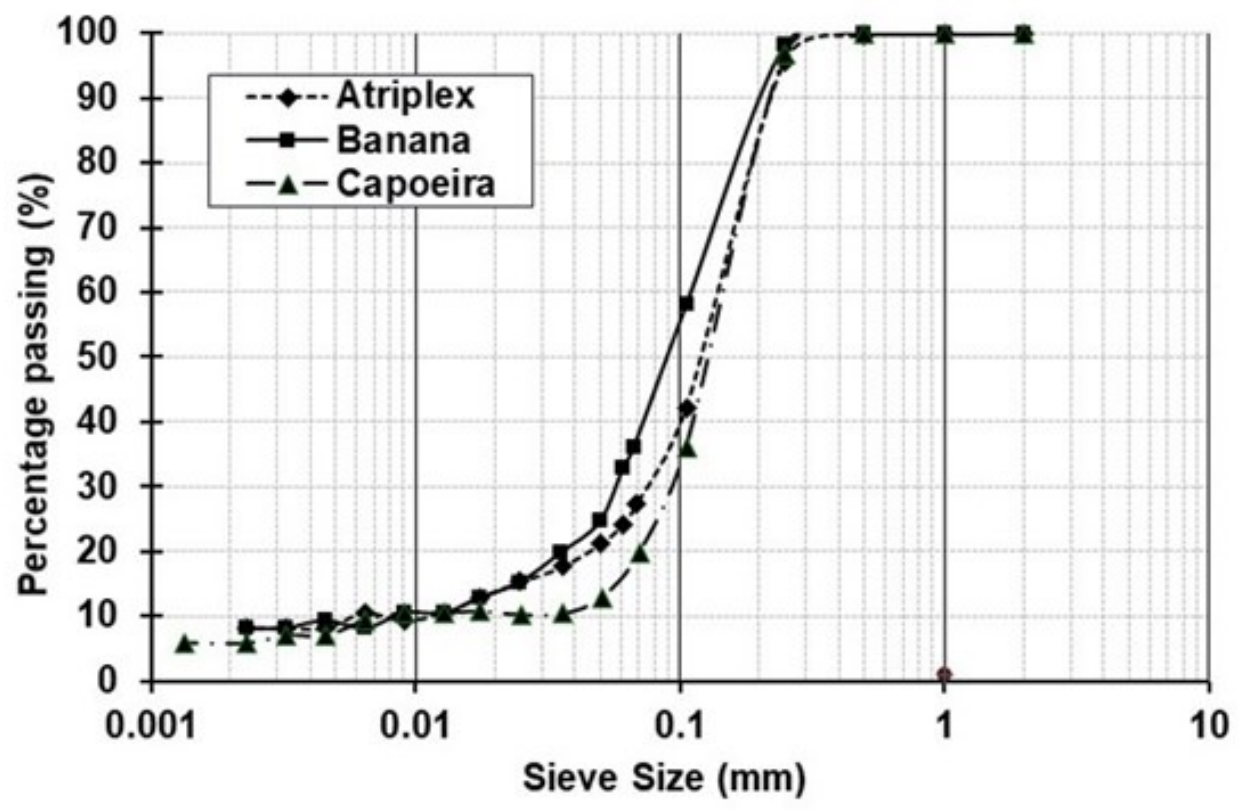

Figure 2. Particle size distribution for the study three areas: Atriplex, Capoeira and Banana.

\section{Soil Chemical Analysis}

Table 3 presents the chemical composition of the soil in the studied areas. It can be observed a soil rich with exchangeable bases of average fertility in the areas with Atriplex and Capoeira and high fertility in the area with Banana. The $\mathrm{pH}$ was in the ideal range, corroborating with the low values of
$\mathrm{Al}^{+3}$ and $\mathrm{H}^{+}$, and there was no need for any correction regarding the degree of acidity. Depending on the soil conditions and climate of the region where the experiment was performed, the levels of organic matter were average. This attribute did not limit the development of the crop, either by its toxic effects or by the nutritional imbalance as a function of its ionic concentration in the soil.

Table 3. Chemical composition of the Fluvic Cambisol obtained from the soil collection in the three study areas.

\begin{tabular}{|c|c|c|c|c|c|c|c|c|c|c|c|c|}
\hline Sample & $\mathrm{pH}$ & $\mathrm{P}$ & $\mathrm{K}^{+}$ & $\mathrm{Na}^{+}$ & $\mathrm{Al}^{3+}$ & $\mathrm{Ca}^{2+}$ & $\mathrm{Mg}^{+2}$ & $\mathrm{H}^{+}$ & BS & CEC & O.M. & SAR \\
\hline & $\mathrm{H}_{2} \mathrm{O}$ & $\mathrm{mg} \cdot \mathrm{dm}^{-3}$ & & & \multicolumn{5}{|c|}{$\mathrm{cmol}_{\mathrm{c}} \cdot \mathrm{dm}^{-3}$} & \multicolumn{3}{|c|}{ g. $\mathrm{kg}^{-1}$} \\
\hline Atriplex & 7.0 & 80 & 0.54 & 0.12 & 0.0 & 4.40 & 1.00 & 1.80 & 7.06 & 8.86 & 9.5 & 0.07 \\
\hline Capoeira & 6.6 & 120 & 0.37 & 0.03 & 0.0 & 3.30 & 2.00 & 1.70 & 4.70 & 6.40 & 5.9 & 0.02 \\
\hline Banana & 7.4 & 80 & 0.28 & 0.83 & 0.0 & 4.50 & 1.70 & 1.50 & 7.31 & 8.81 & 8.8 & 0.47 \\
\hline
\end{tabular}

BS - Sum of bases; CEC - Cation exchange capacity; O.M. - Organic matter; SAR - Sodium adsorption ratio.

\section{Hydrodynamic Characterization}

In obtaining data for the hydrodynamic characterization of the soil, Figure 3 shows the mean curves of cumulative infiltration versus time for the three study areas. The last four values of each curve (highlighted) refer to the solute $\mathrm{KBr}\left(1 \mathrm{~mol} . \mathrm{L}^{-1}\right)$ infiltration. For each graph, the estimated values of the sorptivity $(S)$ and saturated hydraulic conductivity $\left(K_{s}\right)$ are shown. The saturated hydraulic conductivity, which ranged from 14.7 to $35.3 \mathrm{~cm} . \mathrm{h}^{-1}$, was considered high, but within the range of variation found by Souza et al. (2007) for a Fluvisol of the same textural class. 


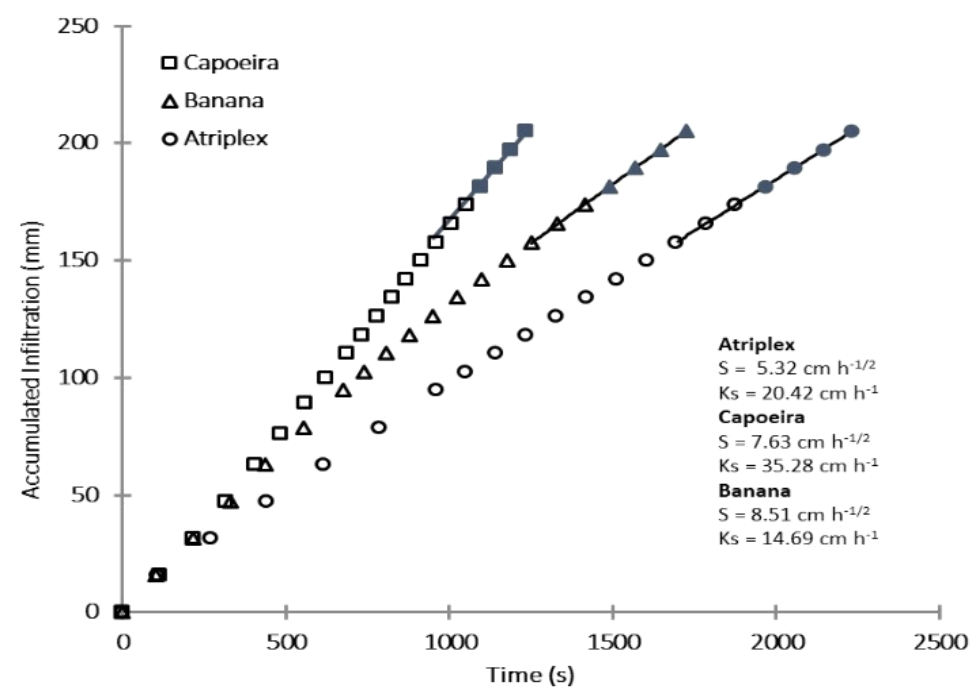

Figure 3. Cumulative infiltration curve ( $\mathrm{mm}$ ) versus time (s) at the points of the experimental tests.

The Fluvic Cambisol presented only one hydrodynamic characteristic: high values of $S$ associated with high values of $K_{s}$. Since the value of $S$ reflects the initial conditions of the soil surface, mostly indicating the presence, or not, of an impediment crust to the infiltration, the high values suggest that the Fluvic Cambisol is resistant to the superficial crust caused by raindrops or soil management. Souza et al. (2007) evaluated and verified that the effect of the presence of crust formed by the disintegration of the aggregates, in a castor bean crop (Ricinus communis L.), due to the direct impact of the raindrops significantly influenced $K_{s}$ and $S$, by approximately $50 \%$.

The observed hydrodynamic condition (high values of $S$ and $K_{s}$ ) demonstrates the good agricultural potential of Fluvic Cambisol, mainly in irrigated areas in semi-arid regions, where climatic factors favor salinization. The good natural drainage promoted by the high quantity of sand, favors the lixiviation of salt and minimizes the salinization risks. The low values of the sodium adsorption ratio (SAR), below 0.47 , demonstrate that the soil was not under the harmful effect of $\mathrm{Na}^{+}$even when submitted with irrigation. Ropelewska and Zapotoczny (2017) reported that excess salt could lead to the degradation of arable land and to the exclusion of agriculture production due to the aggravation of the soil's physicochemical and microbiological properties.

According to Table 4, the high values of $K_{s}$ are related to the loamy sand soil texture. The macropores in the sandy soils operate as preferential flow paths, causing fast water and solute movement in the soil profile. Van der Heijden et al. (2013), studied the influence of preferential flow and observed that nutrient leaching was underestimated by up to 2.5 times when the preferential flow was not taken into account in the simulations with the Hydrus $-1 \mathrm{D}$ model. For the authors, when all the micropores are filled with water, the excess water fills the macropores, thus generating the preferential flow.

Table 4. Hydrodynamic parameters, time, and characteristic mean lengths.

\begin{tabular}{|c|c|c|c|c|c|c|c|}
\hline Areas & $\begin{array}{l}\rho_{\mathrm{d}}{ }^{*} \\
\text { g.cn }\end{array}$ & ${ }_{-3}^{D p}$ & $\theta_{\text {ini }}$ & $\begin{array}{l}\theta_{\mathrm{f}} \dagger \\
\mathrm{cm}^{3} \cdot \mathrm{cm}^{-3}\end{array}$ & $\Delta \theta$ & $\begin{array}{l}\mathrm{S} \\
\mathrm{cm} \cdot \mathrm{h}^{-1 / 2}\end{array}$ & $\begin{array}{l}\mathrm{K}_{\mathrm{s}} \\
\mathrm{cm} \cdot \mathrm{h}^{-1}\end{array}$ \\
\hline Atriplex & $1.251 \pm 0.000$ & 2.62 & 0.023 & $0.274 \pm 0.024$ & 0.251 & 5.32 & 20.42 \\
\hline Capoeira & $1.284 \pm 0.025$ & 2.56 & 0.038 & $0.312 \pm 0.015$ & 0.274 & 7.63 & 35.28 \\
\hline Banana & $1.165 \pm 0.052$ & 2.52 & 0.066 & $0.402 \pm 0.011$ & 0.336 & 8.51 & 14.69 \\
\hline
\end{tabular}

* Mean and standard deviation of three values per point.

$\dagger$ Mean and standard deviation of fifteen values per point.

From the data in Table 4, the direct relationship between soil sorptivity and variation of the volumetric water content can be observed. The area with Atriplex, had a lower variation in volumetric water content $\left(\Delta \theta=0.252 \mathrm{~cm}^{3} . \mathrm{cm}^{-3}\right)$ when compared with the areas with Capoeira $(\Delta \theta=$ $\left.0.274 \mathrm{~cm}^{3} \cdot \mathrm{cm}^{-3}\right)$ and Banana $\left(\Delta \theta=0.336 \mathrm{~cm}^{3} \cdot \mathrm{cm}^{-3}\right)$, and it had a lower $S$ value. The particle size distribution presented in Figure 2 shows the soil with Atriplex had a higher percentage of fine material (fine sand and silt), which promotes a higher interaction with water and reactive solutes in the soil. 


\section{Hydrodispersive Characterization}

In Table 5 are shown the values of soil hydraulic properties, determined experimentally and the application time of the $\mathrm{KBr}$ solute tracer for the miscible displacement carried out in the field. The one-dimensional flow $\left(q_{1 D t s o l}\right)$ was used to calculate the water mean velocity in the pores $\left(v_{\text {cal }}\right)$, following the consideration that the samples were collected at the central infiltrometer axis, where the onedimensional is constant at the end of the infiltration test. Those mean velocities were then used as fixed input data in the CXTFIT 2.0 program for the estimation of the hydrodispersive parameters. The values of $q_{1 \text { Dtsol }}$ agree with the condition imposed by Snow (1999) to validate the hypothesis $\mathrm{C}_{\mathrm{im}}\left(\mathrm{z}_{\mathrm{o}}, \mathrm{t}_{\mathrm{sol}}\right) \approx$ 0 , that is, $\mathrm{C}_{\mathrm{im}}\left(\mathrm{z}_{\mathrm{o}}, \mathrm{t}_{\mathrm{sol}}\right) \approx 0$.
The $I_{\text {sol }}$ values shown in Table 5 , are also in agreement with the condition imposed by Snow (1999) to validate the hypothesis $\mathrm{I}_{\text {sol }}<1.25 \times q_{\text {IDtsol }}$. The solute advance $\left(Z_{\text {forward }}\right)$ variable was also calculated, according to equation (19):

$$
\mathrm{Z}_{\text {forward }}=\frac{\mathrm{I}_{\left(\mathrm{t}_{\mathrm{sol}}\right)}}{\theta_{\text {fin }}}
$$

where the infiltrated of the bromide solution was calculated from the infiltration equation for short times in function of soil sorptivity $(S)$ and soil hydraulic conductivity $\left(\mathrm{K}_{\mathrm{s}}\right)$ calculated at hydrodynamic parametrization.

Table 5. Values concerning the application of the solute in the three studied areas.

\begin{tabular}{lcccccc}
\hline \multicolumn{1}{c}{ Areas } & $\begin{array}{c}\theta_{\text {fin }}^{\dagger} \\
\left(\mathrm{cm}^{3} \cdot \mathrm{cm}^{-3}\right)\end{array}$ & $\begin{array}{c}\mathrm{C}_{\text {ini }} \\
\left(\mathrm{mg}^{-1}\right)\end{array}$ & $\begin{array}{c}\mathrm{q}_{1 \text { Dtsol }} \\
\left(\mathrm{cm}^{-1}\right)\end{array}$ & $\begin{array}{c}\mathrm{v}_{\text {cal }} \\
\left(\mathrm{cm}^{-1}\right)\end{array}$ & $\begin{array}{c}\mathrm{Z}_{\text {forward }} \\
(\mathrm{cm})\end{array}$ & $\begin{array}{c}\mathrm{I}_{\text {sol }} \\
(\mathrm{mm})\end{array}$ \\
\hline Atriplex R1 & $0.291 \pm 0.041$ & 0.20 & 29.34 & 74.2 & 8.71 & 25.89 \\
Atriplex R2 & $0.257 \pm 0.029$ & 0.20 & 23.35 & 44.7 & 6.62 & 18.33 \\
Capoeira R1 & $0.318 \pm 0.025$ & 0.19 & 61.20 & 125.2 & 7.28 & 23.15 \\
Capoeira R2 & $0.295 \pm 0.033$ & 0.20 & 50.76 & 101.4 & 6.35 & 23.27 \\
Capoeira R3 & $0.323 \pm 0.053$ & 0.50 & 73.80 & 145.7 & 9.72 & 22.14 \\
Banana R1 & $0.394 \pm 0.047$ & 0.23 & 33.12 & 64.7 & 6.83 & 26.93 \\
Banana R2 & $0.409 \pm 0.062$ & 0.17 & 30.24 & 68.8 & 6.79 & 27.81 \\
\hline
\end{tabular}

$\uparrow$ Mean and standard deviation of fifteen experimental values per point.

Both the CDE model (two parameters to be adjusted: $D$ and $R$ ) and the MIM model (four parameters to be adjusted: $D, R, \omega$, and $\beta$ ) adequately described the $\mathrm{KBr}$ leaching profiles (Figure 4), with coefficients of determination $\left(\mathrm{R}^{2}\right)$ varying from 0.948 to 0.997 for the $\mathrm{CDE}$ model and 0.531 to 0.997 for the MIM model (Tables 6 and 8 ).

Comparing the models using the $\mathrm{R}^{2}$ values and the standard deviations of the estimates, it can be observed that the CDE model provides the best fit to the experimental data, with an adequate representation of the physical behavior. For the MIM model, in most estimations, the value of the standard deviation is the same order of magnitude or greater than the estimated value (Table 8). According to Milfont et al. (2006), when several parameters are optimized, the non-singularity problem arises due to correlation between the parameters and, in this case, deducing physical meanings from uncertain parameters obtained with the MIM model can be extremely risky. The parameters $\beta$ and $\omega$, estimated using the MIM model, did not present adjustments that represented any physical meaning.

The area with Atriplex had similar hydrodispersive behavior to the area with Capoeira, except for point R3, which was similar to the area cultivated with Banana, where we observed the predominance of hydrodynamic dispersion. The effect of hydrodynamic dispersion can be seen in Table 6, which includes the adjustments of the hydrodispersive parameters generated by the CXTFIT program, considering the CDE model. The hydrodynamic dispersion coefficient $(D)$ varied from 5.54 to $172.8 \mathrm{~cm}^{2} \cdot \mathrm{h}^{-1}$, demonstrating the high spatial variability of this parameter in the studied soil. According to Renard et al. (1977), it is necessary to have a great sensitivity regarding the measurement errors, when it comes to the hydrodynamic dispersion coefficient. Godoy, Zuquette and GómezHernández (2019) when working with an Oxisol, obtained results between 4.2 and $2341 \mathrm{~cm}^{2} . \mathrm{h}^{-1}$, which confirms the high spatial variability of this parameter. The explanation may lie in the arrangement of the mineral particles. A soil, even having the same particle fractions, may have different hydrodynamic characteristics due to the differentiated arrangement of the sand, silt, and clay fractions, promoted by local conditions. 

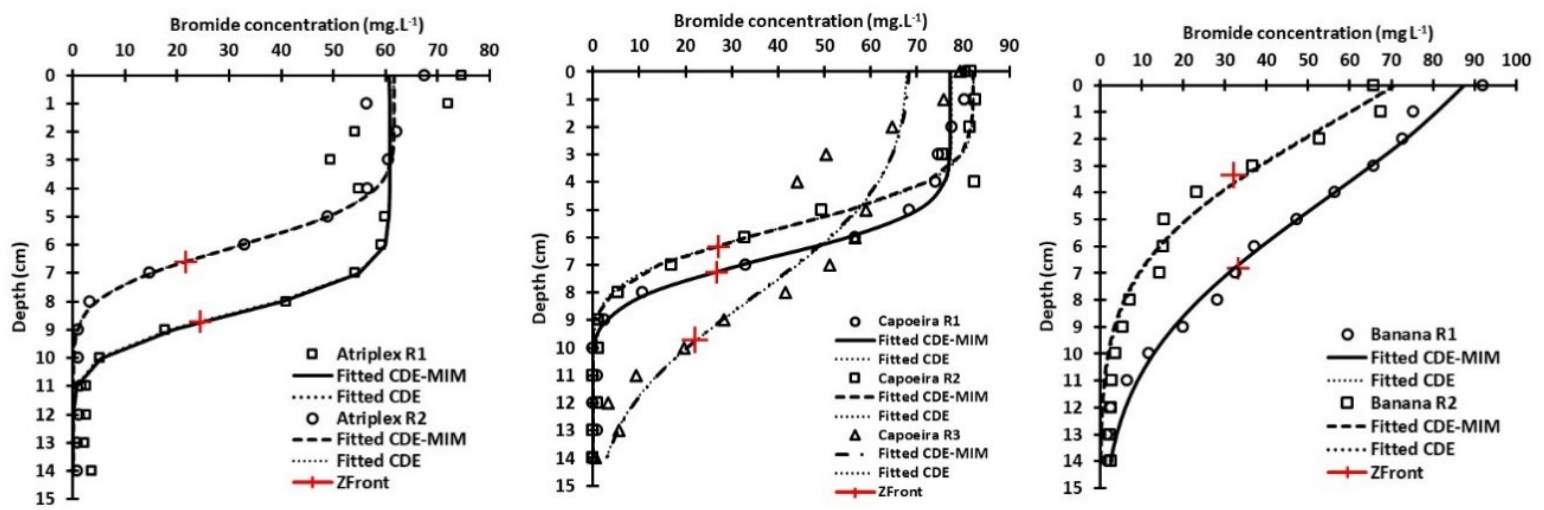

Figure 4. Profiles of bromide concentrations for both the experimental results and those adjusted by the CDE and CDEMIM models, for the Atriplex, Capoeira, and Banana areas.

Retardation factor values were calculated for the ion bromide in the Fluvic Cambisol, in most cases they were below to unit, ranging between 0.518 to 1.491 (Table 6). For chemical tracers, a retardation factor value close to the unit was expected, indicating non-reactivity with the soil. However, in field studies where preferential flow prevails, values are expected in the range observed in this study (Table 6). Thomasson and Wierenga (2003), studied the spatial variability of the retardation factor in field conditions and also found this factor varied between 0.52 to 1.17 , similar to that found in this research. The observed retardation factors reinforce the possibility of preferential flow occurring during the infiltration test and allow us to infer that miscible displacement assays in laboratory columns, commonly used to estimate the hydrodispersive parameters of soil solutes, tend to underestimate the parameters.

Table 6. Results of the hydrodispersive parameter adjustments using the CDE model in the CXTFIT 2.0 program.

\begin{tabular}{lcccccc}
\hline Areas & $\begin{array}{c}v_{c a l} \\
\left(\mathrm{~cm}^{-1}\right)\end{array}$ & $\begin{array}{c}D^{\dagger} \\
\left(\mathrm{cm}^{2} . \mathrm{h}^{-1}\right)\end{array}$ & $R^{\dagger}$ & $\begin{array}{c}\lambda \\
(\mathrm{mm})\end{array}$ & $P$ & $\mathrm{R}^{2}$ \\
\hline Atriplex R1 & 74.2 & $5.54 \pm 3.33$ & $0.659 \pm 0.019$ & 0.747 & 116.59 & 0.948 \\
Atriplex R2 & 44.7 & $6.53 \pm 1.38$ & $0.521 \pm 0.009$ & 1.462 & 45.30 & 0.993 \\
S. Atriplex R1 & 125.2 & $15.82 \pm 1.99$ & $0.695 \pm 0.006$ & 1.264 & 57.61 & 0.997 \\
S. Atriplex R2 & 101.4 & $18.90 \pm 4.60$ & $0.804 \pm 0.018$ & 1.864 & 34.07 & 0.990 \\
S. Atriplex R3 & 145.7 & $100.0 \pm 54.0$ & $0.518 \pm 0.037$ & 6.863 & 14.20 & 0.910 \\
Banana R1 & 64.7 & $149.7 \pm 38.9$ & $0.654 \pm 0.052$ & 23.14 & 2.95 & 0.991 \\
Banana R2 & 45.3 & $172.8 \pm 163.4$ & $1.491 \pm 0.723$ & 38.15 & 0.88 & 0.972 \\
\hline
\end{tabular}

$\dagger$ Value and mean square error.

The dispersivity $(\lambda)$, which has been applied to physically represent the characteristic length of solute transport (VILLERMAUX; VAN SWAAIJ 1969; YULE; GARDNER, 1978; FASHI, 2015), has met the condition Isol $>\lambda$, established by Snow (1999) to validate the hypothesis $\mathrm{C}_{\mathrm{m}}\left(\mathrm{z}_{0}, \mathrm{t}_{\text {sol }}\right)=\mathrm{C}_{0}$ (Table 7). The only experimental point that did not meet the conditions imposed by Snow (1999) was the Banana R2, $I_{\text {sol }}=27.81<\lambda=38.15$. Netto et al. (2013) also observed the non-validation imposed by Snow (1999) for some experimental points, but still considered the hypothesis $\mathrm{C}_{\mathrm{m}}\left(\mathrm{z}_{0}, \mathrm{t}_{\mathrm{sol}}\right)=\mathrm{C}_{0}$ to be valid, following the recommendations in Clothier et al. (1995), which reported that for columns $I_{\text {sol }}>15$ $\mathrm{mm}$, the hypothesis $\mathrm{C}_{\mathrm{m}}\left(\mathrm{z}_{0}, \mathrm{t}_{\mathrm{sol}}\right)=\mathrm{C}_{0 \text { can }}$ be considered valid. In this study, the infiltrated $\mathrm{Br}^{-}$ solution $\left(I_{\text {sol }}\right)$ was greater than $15 \mathrm{~mm}$. The discrepancy of the observed values was due to the experimental conditions, that is, as each experimental point presents a different structural arrangement, the flow conditions were different. Thus, these results corroborate the findings of Javaux and Vanclooster (2003), that the dispersivity $(\lambda)$ presented spatial variability and was dependent on the flow conditions.

Table 7. Calculated data demonstrating which experimental points complied with the Snow hypothesis.

\begin{tabular}{lccc}
\hline Areas & $I_{\text {sol }}$ & $\lambda(\mathrm{mm})$ & $I_{\text {sol }}>\lambda$ \\
\hline Atriplex R1 & 25.89 & 0.747 & TRUE \\
Atriplex R2 & 18.33 & 1.462 & TRUE \\
Capoeira R1 & 23.15 & 1.264 & TRUE \\
Capoeira R2 & 23.27 & 1.864 & TRUE \\
Capoeira R3 & 22.14 & 6.863 & TRUE \\
Banana R1 & 26.93 & 23.14 & TRUE \\
Banana R2 & 27.81 & 38.15 & FALSE \\
\hline
\end{tabular}

Rev. Caatinga, Mossoró, v. 33, n. 1, p. 160 - 171, jan. - mar., 2020 
The Péclet number $(P)$ shows which process is predominant, whether its dispersive $(P<10)$ or convective $(P>10)$. Considering the data in Table 6 , it can be inferred that the dispersive effect was predominant in the area with Banana. The other areas (with Atriplex and Capoeira) presented values higher than 10 , indicating that convective flow is predomi- nant. Soil management in banana cultivation makes the physical properties of the soil layers more uniform, favoring the predominance of dispersion. In the areas of Capoeira and Atriplex, the absence of cultural treatments led to the emergence of cracks that promoted preferential flow, favoring the convection process.

Table 8. Results of hydrodispersive parameter adjustments using the MIM model in the CXTFIT 2.0 program.

\begin{tabular}{|c|c|c|c|c|c|c|}
\hline Areas & $\begin{array}{c}v_{\text {cal }} \\
\left(\mathrm{cm}, \mathrm{h}^{-1}\right)\end{array}$ & $\begin{array}{c}D^{\dagger} \\
\left(\mathrm{cm}^{2}, \mathrm{~h}^{-1}\right)\end{array}$ & $R^{\dagger}$ & $\omega$ & $\beta^{*}$ & $\mathrm{R}^{2}$ \\
\hline Atriplex R1 & 74.2 & $5.598 \pm 13.83$ & $0.657 \pm 3.68$ & 100.0 & 0.999 & 0.728 \\
\hline Atriplex R2 & 44.7 & $5.074 \pm 2.73$ & $0.596 \pm 0.459$ & $0.0261 \pm 0.065$ & 0.8485 & 0.994 \\
\hline Capoeira R1 & 125.2 & $10.26 \pm 1.29$ & $0.915 \pm 0.285$ & $0.02607 \pm 0.065$ & 0.8485 & 0.997 \\
\hline Capoeira R2 & 101.4 & $19.67 \pm 6.81$ & $1.72 \pm 1050$ & 1E-6 \pm ----- & 0.9638 & 0.990 \\
\hline Capoeira R3 & 145.7 & $107.3 \pm 257.4$ & $0.523 \pm 6.362$ & 100.0 & 0.9640 & 0.531 \\
\hline Banana R1 & 64.7 & $14.34 \pm 14.60$ & $2.44 \pm 0.95$ & $0.1695 \pm 0.0285$ & 0.2456 & 0.991 \\
\hline Banana R2 & 68.8 & $204.7 \pm 1595$ & $2.023 \pm 198.1$ & $1 \mathrm{E}-6 \pm----$ & 0.999 & 0.971 \\
\hline
\end{tabular}

$\dagger$ Value and mean square error.

$\beta$ '* assumed to be equal to the fraction of mobile water $(\Phi)$

The lack of physical significance for the parameters $\beta$ and $\omega$, determined with the MIM model, meant that the other parameters, such as as $\lambda$, $\alpha$ and $P$, could not be calculated.

\section{CONCLUSIONS}

The Fluvic Cambisol presented a hydrodynamic characteristic portrayed in high values of sorptivity $(S)$ associated with high values of saturated hydraulic conductivity $\left(K_{s}\right)$, indicating that the soil presents good permeability and resistance to surface crumbling caused by rain drops or soil management.

Convective transport was the predominant process, with the hydrodynamic dispersion coefficient $(D)$ and the retardation factor $(R)$ both showing high spatial variability in the studied areas.

The CDE model presented a better performance than the MIM in describing the transport of the $\mathrm{KBr}$ tracer under field conditions, indicating the absence of two water regions, mobile and immobile, in the studied Fluvic Cambisols.

\section{ACKNOWLEDGEMENTS}

The authors thank the Fundação de Amparo à Ciência do Estado de Pernambuco (FACEPE), the Conselho Nacional de Desenvolvimento Científico e Tecnológico (CNPq), and the Coordenação de Aperfeiçoamento de Pessoal de Nível Superior (CAPES) for financial support.

\section{REFERENCES}

BIGGAR, J. W.; NIELSEN, D. R. Miscible displacement in soils: II. Behavior of tracers. 1. Soil Science Society of America Proceedings, 26: 125128, 1962a.

BIGGAR, J. W.; NIELSEN, D. R. Some comments on molecular diffusion and hydrodynamic dispersion in porous media. Journal of Geophysical Research, 67: 3636-3637, 1962b.

BRAGA, J. M.; DEFELIPO, B. V. Determinação espectrofotométrica de fósforo em extratos de solo e material vegetal. Revista Ceres, 21: 73-85, 1974.

BROOKS, R. H.; COREY, A. T. Hydraulic properties of porous media. Hydrology Paper. n. 3, Fort Collins: Colorado State University. 1964. 27 p.

BURDINE, N. T. Relative permeability calculations from pore-size distribution data. American Institute Mining and Metallurgy Engineering, 198: 71-77, 1953.

CLOTHIER, B. E. et al. The measured mobile water content of an unsaturated soil, as a function of hydraulic regime. Australian Journal of Soil Research, 33: 397-414, 1995.

CLOTHIER, B. E.; KIRKHAM, M. B. MCLEAN, J. E. In situ measurement of the effective transport volume for solute moving through soil. Soil Science Society of America Journal, 56: 733-736, 1992.

COATS, K. H.; SMITH, B. D. Dead-end pore volume and dispersion in porous media. Society of 
Petroleum Engineering Journal, 3: 49-52, 1964.

COPPOLA, A. et al. Solute transport scales in an unsaturated stony soil. Advances in Water Resources, 34: 747-759, 2011.

DING, Z. et al. Filtration and transport of heavy metals in graphene oxide enabled sand columns. Chemical Engineering Journal, 257: 248-252, 2014.

DYNIA, J. F.; SOUZA, M. D. BOEIRA, R. C. Lixiviação de nitrato em Latossolo cultivado com milho após aplicações sucessivas de lodo de esgoto. Pesquisa Agropecuária Brasileira, 41: 855-862, 2006.

FASHI, F. H. A review of solute transport modeling in soils and hydrodynamic dispersivity. Agriculture - Science and Practice, 95: 134-142, 2015.

FOOD AND AGRICULTURE ORGANIZATION FAO. World reference base for soil resources 2014: International soil classification system for naming soils and creating legends for soil maps. Rome, 2015. $192 p$

FUENTES. C. et al. Soil water conductivity of a fractal soil. In: BAVEYE. P.; PARLANGE. J. Y.; STEWART. B. A. (eds.). Fractals in soil science. Boca Raton, FL: CRC Press, 1998. cap. 11, p. 333 340.

GHIBERTO, P. J.; LIBARDI, P. L. TRIVELIN, P. C. O. Nutrient leaching in an Ultisol cultivated with sugarcane. Agricultural Water Management, 148: 141-149, 2015.

GODOY, V. A.; ZUQUETTE, L. V. GÓMEZHERNÁNDEZ, J. J. Spatial variability of hydraulic conductivity and solute transport parameters and their spatial correlations to soil properties. Geoderma, 339: 59-69, 2019.

HAVERKAMP, R. et al. Three-dimensional analysis of infiltration from the disc infiltrometer: 2 . Physically based infiltration equation. Water Resources Research, 30: 2931-2935, 1994.

HAVERKAMP, R.; PARLANGE, J. Y. Predicting the water retention curve from particle size distribution: I Sandy soils without organic matter. Soil Science, 142: 325-335, 1986.

JAVAUX, M.; VANCLOOSTER, M. Scale-and ratedependent solute transport within an unsaturated sandy monolith. Soil Science Society of America Journal, 67: 1334-1343, 2003.

LASSABATÈRE, L. et al. Beerkan estimation of soil transfer parameters through infiltration experiments - BEST. Soil Science Society of America Journal, 7: 521-532, 2006.

MILFONT, M. L. et al. Caracterização hidrodispersiva de dois solos do Vale do Rio São Francisco. Revista Brasileira de Ciências Agrárias, 1: 81-87, 2006.

NETTO, A. M. et al. Caracterização hidrodinâmica e hidrodispersiva de um latossolo amarelo na microrregião do brejo paraibano. Revista Brasileira de Ciência do Solo, 37: 86-96, 2013.

NIELSEN, D. R.; BIGGAR, J. W. Miscible displacement in soil: I. Experimental information. Soil Science Society of America Proceedings, 25: 1 $-5,1961$

PHILIP, J. R. The theory of infiltration: 4. Sorptivity and algebraic infiltration equations. Soil Science, 84 : 257-264, 1957

RENARD, J. L. et al. Mesure du coefficient de dispersion hydrodynamic longitudinal dans un milieu poreux saturé. Annales Agronomiques, 28: 47-64, 1977.

RODRÍGUEZ-LIÉBANA，J. A.; MINGORANCE, M. D. PEÑA, A. Thiacloprid adsorption and leaching in soil: Effect of the composition of irrigation solutions. Science of the Total Environment, 610-611: 367-376, 2018.

ROPELEWSKA, E.; ZAPOTOCZNY, P. A calorimetric assessment of the effects of sodium chloride and sodium bromide on the microbiological and thermokinetic characteristics of soil. Geoderma, 288: 1-7, 2017

SANTOS, M.A. et al. Dinâmica de íons em solo salino-sódico sob fitorremediação com Atriplex nummularia e aplicação de gesso. Revista Brasileira de Engenharia Agrícola e Ambiental, 17: 397-404, 2013.

SIDOLI, P. et al. Experimental and modeling of the unsaturated transports of S-metolachlor and its metabolites in glaciofluvial vadose zone solids. Journal of Contaminant Hydrology, 190: 1-14, 2016.

SILVA, F. C. Manual de análises químicas de solos, plantas e fertilizantes. 2, ed. rev. Ampl. Brasília, DF: Embrapa Informação Tecnológica, 2009. 627p.

SNOW, V. O. In situ measurement of solute transport coefficients: Assumptions and errors. Soil Science Society of America Journal, 63: 255-263, 
1999.

SOUZA, E. S. et al. Efeito do encrostamento superficial nas propriedades hidráulicas de um solo cultivado. Revista Brasileira de Ciências Agrárias, 2: 69-74, 2007.

SOUZA. L.S.B. et al. Balanço de Radiação em Ecossistema de Caatinga Preservada Durante um Ano de Seca no Semiárido Pernambucano. Revista Brasileira de Geografia Física, 8: 041-055, 2015.

TEIXEIRA, P. C. et al. Manual de métodos de análise de solo. 3, ed. rev. e ampl. Brasília, DF: Embrapa Solos, 2017. 573 p.

THOMASSON, M. J.; WIERENGA. P. J. Spatial variability of the effective retardation factor in an unsaturated field soil. Journal of Hydrology, 272: 213-225, 2003.

TOCCALINO, P. L. et al. Pesticides in Groundwater of the United States: decadal-scale changes. 19932011. Groundwater-Focus, 52: 112-125, 2014.

TORIDE, N.; LEIJ, F. J. VAN GENUCHTEN, M. TH. The CXTFIT code for estimating transport parameter from laboratory or field tracer experiments. Version 2.0. Riverside: U.S. Salinity Laboratory. ARS-USDA. CA. 1995. 131 p.

VAN DER HEIJDEN, G. et al. Tracing and modeling preferential flow in a forest soil - Potential impact on nutrient leaching. Geoderma, 195-196: 12 $-23,2013$.

VAN GENUCHTEN, M. Th. A closed-form equation for predicting the hydraulic conductivity of unsaturated soils. Soil Science Society of American Journal, 44: 892-898, 1980.

VAN GENUCHTEN, M. Th.; WIERENGA, P. J. Mass transfer studies in sorbing porous media. I. Analytical solutions. Soil Science Society of America Journal, 40: 473-480, 1976.

VILLARREAL, R. et al. Diffusivity and sorptivity determination at different soil water contents from horizontal infiltration. Geoderma, 338: 88-96, 2019.

VILLERMAUX, J.; VAN SWAAIJ, W. P. M. Modèle representatif de la distribution des temps de séjour dans un reacteur semi-infini a dispersión axiale avec zones stagnantes. Aplications a leécoulement ruisselant dans des colonnes d"eanneaux Raschig. Chemical Engineering Science, 24: 1097-1111, 1969.
VOGELMANN, E. S. et al. Soil moisture influences sorptivity and water repellency of topsoil aggregates in native grasslands. Geoderma, 305: 374-381, 2017.

YULE, D. F.; GARDNER, W. R. Longitudinal and transverse dispersion coefficients in unsaturated plainfield sand. Water Resources Research, 14: 582-588, 1978 . 